\title{
Dilating Low-Income Housing Financing: Lessons for Emerging Market REITs
}

\author{
Ezinne Ifeoma Onyekwelu ${ }^{1} \quad$ Paul Chuks Anih ${ }^{2} \quad$ Chinelo Ifenyinwa Nwaibe $^{3}$ \\ 1.Estate Management, University of Nigeria Nsukka, Enugu, Nigeria \\ 2.Estate Management, University of Uyo, Akwa Ibom, Nigeria \\ 3.Estate Management, Caritas University, Enugu, Nigeria
}

\begin{abstract}
Asymmetric movements of housing demand and supply has consequently led to extraordinary house price increments, thereby making housing unaffordable and unsustainable for significant proportion of urban settlers in many emerging economies. This deficit in low-income housing delivery strengthens the pertinence of looking elsewhere for solutions. With the emergence of REITs as a vast source of real estate financing, literature has identified the potential of this investment vehicle in financing low-income housing delivery in the form of social purpose REITs. Worryingly, studies on the applicability of these REITs in financing low-income housing is almost inexistent in emerging economies, outside China. The study is aimed at the examination of empirical literature on the use of social purpose REITs as vehicle for ameliorating low-income housing delivery with a view to extricating pertinent lessons for emerging market REITs. Content analysis was conducted using TEXTPACK; and the resulting synthesis of extant literature produced 4 main lessons for emerging market REITs. It was concluded that to dilate the financing of low-income housing delivery, REITs in emerging markets should adopt policies that encourage the establishment of social purpose REITs. Such policies should lend towards the implementation of tax credits to social purpose REITs and an exemption of low-income housing developers from development costs. Also, PublicPrivate Partnerships for housing delivery should be reviewed to incorporate strategies that ameliorate indemnificatory housing, while the mortgage system should be revamped to accommodate mortgage tranche and long-term debt capitalization.
\end{abstract}

Keywords: Low-income housing delivery, Social purpose REITs, housing finance, REITs, Emerging Markets

DOI: $10.7176 / \mathrm{EJBM} / 12-18-05$

Publication date:June 30 th 2020

\section{Primer}

Rental affordability issues have forced a significant proportion of urban settlers in lower middle-income countries into contiguous settlements, constituting a crisis of management for respective governments. Putting this into perspective, only a trifling 3\% of Africans can afford a mortgage (African Development Bank in Kieti \& K'Akumu, 2017 ), in addition to estimated $65 \%$ of the continent's urban population deprived of formal settlement due to high occupant affordability ratios (UN-Habitat, 2008; World Bank, 2015). Evidence from the same statistics show that Zimbabwe had the lowest 'urban population by shelter deprivation' with less than $20 \%$, while Sierra Leone's was highest with over $90 \%$. West African countries Mali and Nigeria, slightly surpassed the continent's average of $65 \%$. In view of such statistics, it can be deduced that the asymmetric movements of housing demand and supply has consequently led to extraordinary house price increments.

Figure 1 elucidates this argument with the occupant affordability ratio of households in selected emerging markets:

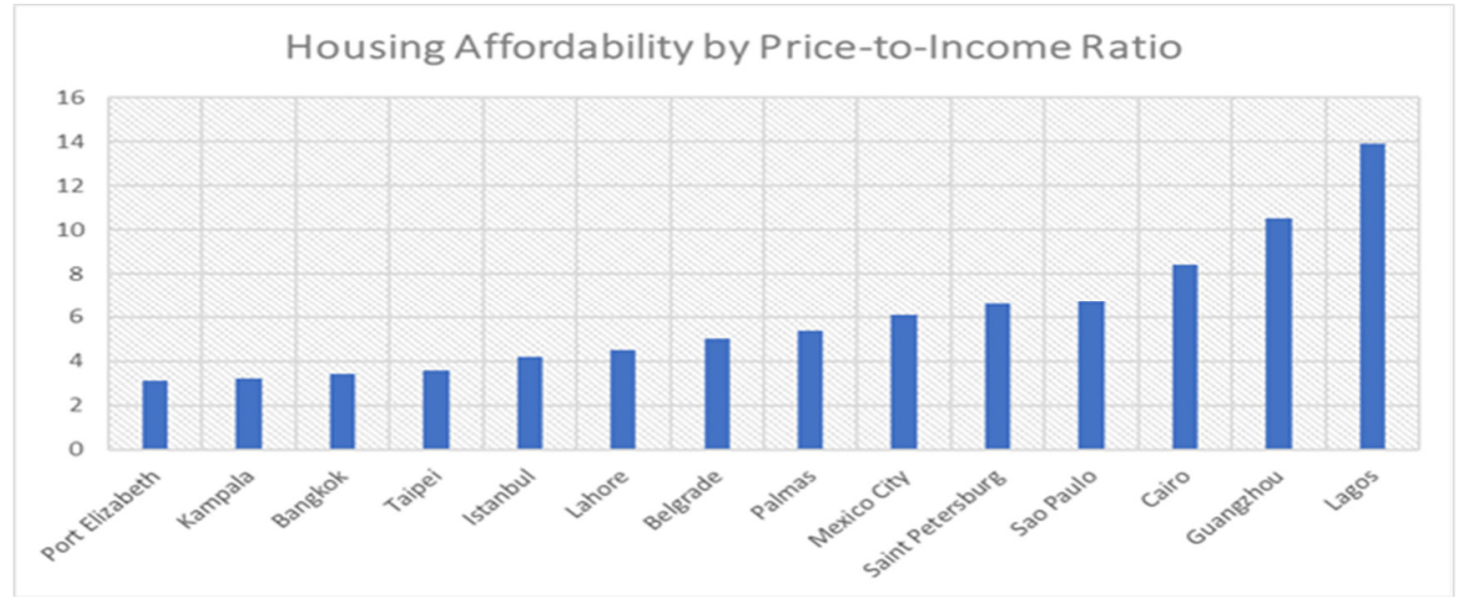

Figure 1: Price-to-Income Ratios of Urban Households in Emerging Markets Source: Kallergis et al (2018) 
Figure 1 is a cross-section of Kallergis et al (2018) global price-to-income ratio of urban households, which we developed to magnify cities in emerging economies. There appears a consensus in extant research on the tagging of 3.0 price-to-annual income ratio of households as standard occupant affordability, while greater than 5.1 implies severe unaffordability (Sani \& Rahim, 2015; Kallergis et al, 2018; Suhaida et al, 2011). Thus, at between 6.1 to 13.9 occupant affordability ratios, housing units in cities such as Mexico City, Saint Petersburg, Sao Paulo, Cairo, Guangzhou and Lagos are severely unaffordable, with Guangzhou and Lagos most acutely so. Usually, low-income households fall within the occupant affordability ratio of 13.1, 9.24 for medium income, and 3.68 for high income group (Nsiah-Gyabaah, 2009; Sani et al, 2015). Such depictions imply that countries whose occupant affordability ratios hover around the 13-point mark, are at the low end of the income spectrum with a dominant low-income demography.

Hence, countries within this occupant affordability category are in more need of low-income housing delivery, but the prioritization of this housing category has been met with several challenges. One critically resounding and recurring theme among challenges of low-income housing delivery is finance (Kieti et al, 2018; Suhaida et al, 2011; Gillespie, 2018; Aliu et al, 2018). Perhaps a befitting eulogy to the housing-finance dyad can be found in Afolayan's (2017) avowal that "housing delivery is very sensitive to the structure and operations of financing available for it". This may offer explanation for the seeming insurmountable challenge of accumulating requisite resources for housing that meets the demand of the teeming and growing low-income demography, due to continued and mounting economic and budgetary austerity in many developing countries. It is thus evident that we must look elsewhere for solutions.

Already, traditional sources of housing financing such as equity funds, family sources, mortgages, deposit money bank lending and cooperatives have proved inadequate in facilitating the low-income housing stock (Ebi \& Kalu, 2016; Montgomery et al, 2018); while arguably more contemporary sources such as consociate capital, contractor financing, hedge funds, venture capitalization, crowdfunding, and Real Estate Investment Trusts (REITs) are hardly bereft of difficulties (Moosa, 2020; Deng et al, 2018; Vismara, 2018; Cao \& Zhao, 2018). Since its establishment by statute in 1960 by the United States Congress, REITs in particular, have been adjudged one the fastest growing real estate finance sources, comprising over 200 regimes across over 37 countries, and a market capitalization of over $\$ 1.7$ trillion. We examine this huge source of housing financing and how it can be leveraged for increased low-income housing delivery.

\section{Real Estate Investment Trusts}

The United States Securities and Exchange Commission in 2011 described REIT as "company that owns - and typically operates - income-producing real estate or real estate-related assets" cutting across all sectors of the real estate market. They were established for the main purpose of stimulating growth in large-scale income-producing real estate investment through reduced risks, increased transparency and more flexible tax regimes (Brounen \& de Konin, 2012). One practical advantage of REITs that begets shareholding and scholarly interest is its liquidity physiognomy, unlike direct real estate, in addition to its remittance of up to $90 \%$ taxable income to shareholders.

Over the past few years, research on REITs have focused on generating capital for real estate investment through 3 main investment strategies - mortgage REITs, equity REITs, and hybrid REITs. Equity REITs are most common globally, and they refer to listed companies that own and operate income-generating real estate investments (Chan, 2016; Liu et al, 2013). Equity REITs require no less than 50 shareholders, thereby providing opportunity of diverse array of investors across a broad spectrum of real estate portfolios. Mortgage REITs, on the other hand, do not invest directly in real estate. Instead, they provide loans to real estate investors through direct mortgage, or indirectly through mortgage backed securities. As the name implies, hybrid REITs utilize both equity and mortgage REIT investment strategies. We examine empirical submissions of the merits of REITs in housing delivery.

\section{REITs and Housing Delivery}

REITs are playing a significant role in the housing industry (Strauss, 2018). There is a plethora of similar studies acclaiming the intrinsic worth of real estate investment trusts to housing. In reviewing them, we followed a qualitative approach, taking into cognizance peer reviewed studies domiciled on the Web of Science, SSRN, SCOPUS, Harvard DSpace and Google Scholar databases. Content analysis was conducted using TEXTPACK; and the resulting synthesis of extant literature produced 5 main contributions of REITs to housing delivery, while exposing the research lacuna. The contributions are:

a. Flexible Tax Regime

Afolayan (2017) submits that REITs who pay up to $95 \%$ of their profits as dividends to shareholders are not expected to pay tax, but the tax obligation falls on shareholder income. Yet, some flexibility may be allowed here for shareholders. The US SEC avers that investors may wish to defer tax by opening tax-deferred accounts such as a retirement account. This flexibility, in addition to the possibility of higher dividend payments as a result of the non-taxed REIT profit, provide an alluring appeal to real estate investors (Cai, 2017; Strauss, 2018). 


\section{b. Relatively High Liquidity}

One of the characterizations of direct real estate investment is its illiquidity. The illiquidity physiognomy of this category of real estate investment arises from its typically high value which renders its purchase to the domain of a privileged few, especially in emerging markets. This unaffordability criterium becomes more magnified in countries with weak mortgage systems, thereby making such investments difficult to sell. However, REITs are unique in their hybrid of direct real estate and stock market features. As real estate, it is almost guaranteed to generate higher incomes due to its appreciable nature; as a traded security, investors can easily raise capital through sale of shares, as against the longer time it usually takes to sell property in the open market (Newell \& Marzuki, 2018; Cai, 2017). Faced with this more liquid class of realty investment, more investors are attracted to commit funds towards real estate development, thereby boosting the housing industry (Carstens \& Freybote, 2018; Huang, 2010).

c. Diversifiable

The Capital Asset Pricing Model advocates for the elimination or relaxation of investment risk through diversification, and the fact that REITs provide archetypal demonstration of this theory is good news for riskaverse investors in less stable and inefficient markets of emerging economies. REIT offers investors the opportunity of owning real estate investments across a spectrum of sectors and geographical areas, which would have been more cumbersome to accomplish individually (Lin et al, 2019; Marzuki \& Newell, 2018; Cai, 2017; Boudry et al, 2016). The attraction to investors is that capital outlay required for one real estate investment class is diversifiable by REIT investment into an array of several investment classes, thereby reducing negative impacts of risk on returns.

d. Professional Management

REITs offer sound professional business and financial management services at far reduced cost to investors who would have paid more for such services at the individual level (Afolayan, 2017; Huang, 2010; Cai, 2017). Also, increased access to professional management services within REIT portfolios contribute to its superior performance over direct real estate investments (Marzuki \& Newell, 2019; Lin et al, 2019; Newell et al, 2018). In context, such benefits save the investor from whatever investment management skill deficiency they may likely possess; thus, fostering more entry into the shareholding with positive externalities to housing delivery for apartment REITs.

Perhaps the assertion that management is a key problem associated with low-income housing, also extending to multi-dwelling units, (Muyingo, 2016; Kyro et al, 2012) is an apposite highlight of the attractiveness of professional management services. If so, one can safely imagine the prospects this can bring to the REIT-financing of such real estate investment class. Hardin III et al (2009) offer a clear and empirical elucidation with a comparative analysis of the impact of ownership and management structure on property level performance amongst traded and direct real estate. The study found that multifamily properties owned and managed by REITs generated "higher effective rents at the property level than non-REIT owned properties".

e. Lesser Capital Requirement

One of the main physiognomies of direct real estate investment is its requirement of huge capital outlay. Countering this posture is REIT, which ensures that capital is pooled from an array of investors, thereby offering each investor the land ownership status desired at a lesser cost. Also, investment benefits and liability are shared amongst shareholders, reducing the burden that would have been borne by a single investor. This is one the main drivers of REIT attraction to real estate investors, as it grants access to ownership of premium properties which would have been more expensive for a single investor (Cai, 2017).

\section{Gap in Literature}

While we do not disregard these REIT benefits to stimulated housing delivery, what we find perturbing is the rate of their low-income housing investment absorption which has contributed to the severe disinvestment in that asset class. To address this, there are clarion calls for a disruptive force in low-income housing financing, with a consideration of social purpose REITs intensifying. Coming closer to the narrative, Marzuki et al (2019) posit that there is an upsurge in recent interest in the role of REITs in "social infrastructure property sectors as healthcare, care facilities and nursing homes". While commendable, it is worth noting that low-income housing, another social venture, is conspicuous in its absence.

Advocating for the place of low-income housing in the social REITs discourse, Cote \& Tam (2013) argue that low-income housing providers globally are struggling to maintain their existing stock. One can safely presume from this argument that the evident struggle in maintaining existing stock, may serve as distraction to the efforts targeted at increasing the stock. Therefore, we examine empirical literature on the use of social purpose REITs as vehicle for ameliorating low-income housing delivery. This examination is motivated by the worrying evidence, as can be found in emerging markets like Nigeria with a housing deficit of over 17 million units (World Bank, 2018); and the attendant negative externalities to increasing occupant affordability ratio-imposed poverty and societal vices (Ewurum, Egolum and Ogbuefi, 2019). 


\section{Social Purpose REITs}

"Literature pertaining to social purpose REITs is limited in nature" (Sgro, 2017). The few available studies do not unite in nomenclating REIT-financing of low-income housing as social purpose REIT due to other nomenclatures as 'affordable housing REITs', 'low-rent housing REITs', 'social housing REITs', and 'multi-dwelling unit REITs'. A synthesis of these nomenclatures reveals two outcomes, one is the confederacy of meaning, two is the prevalence of the 'social purpose REIT' terminology.

We follow suit, and accordingly define social purpose REIT as real estate investment companies "that provide a private market, mission-driven solution for increased affordable housing development" (Ades, 2016). It is a business trust that combines the capital of several investors to provide financing for all forms of low-income housing (Liu et al, 2013). By implication, social purpose REIT in consistence with the merits of REITs to housing delivery, is a quicker platform for generating capital for low-income housing delivery (Robaton, 2020; Sgro, 2017; Ades, 2016). It provides a safety net for low-income households with subsidized rent-geared-to-income housing units due to increased financial flexibility (Cote et al, 2013).

The United States Government defines low-income population as "cost burdened households who spend over $30 \%$ of their income on housing, thereby depleting capital allocation for groceries, healthcare and other essentials" (Robaton, 2020). This representation of the low-income demography aids the definition of affordable housing as "housing whose rents are at, or below $80 \%$ of the average market rent" (Davis, 1997). Sgro (2017) extends the definition of low-income housing as housing whose rent does not exceed $30 \%$ of annual income of the low-income and middle-income demography. Simply put, it is housing for the low-income demography, and funds generated by social purpose REITs are used in consistence with the constructive documents to develop, acquire, manage, and maintain such properties (Liu et al, 2013).

The budgetary constraints and weak mortgage institutions amidst rising low-income demography that characterize emerging economies contribute to the hyped necessity of social purpose REITs (Huang, 2019). Considerations on aligning REITs to the delivery of low-income housing emanated in the 1950s when Morris Milgram established the Mutual Real Estate Investment Trust (M-REIT) to develop 300 units of "integrated housing" that targets low-income minorities in the United States, delivering a dividend value of 7\% in the first year (Huang, 2010). Since then social purpose REITs such as Bridge Housing, Eden Housing LINC Housing Corporation, and Mercy Housing have followed, with Housing Partnership Equity Trust (HPET) and Community Development Trust domiciled in the United States the best-known. The REITs were established as a collaboration of real estate investors and nonprofit organizations committed to the delivery of affordable housing for the lowincome population (Ades, 2016). To what extent have these business trusts enhanced low-income housing delivery? We address this query with an empirical review with a view to extricate pertinent lessons for emerging market REITs.

\section{The Social Purpose REIT - Low-Income Housing Nexus: An Empirical Review}

The application of REIT-financing to social projects, especially infrastructure delivery, is not a new phenomenon, and obviously not alien to emerging economies. For instance, Owusu-Manu et al (2015) conducted a survey of 53 real estate developers in Kumasi, Ghana to ascertain the dominant infrastructure financing source and inherent constraints. The study collected primary data through questionnaire, and employed Relative Important Index in ranking the finance sources and constraints. Findings show that the dominant source of infrastructure financing was debt financing through short-term bank loans and mortgages; while the constraints to that source were legislation, macroeconomic barriers, collateral considerations, inadequate risk assessment, and dearth of financial mobilization mechanisms.

Yet, it is pertinent to stress the diversion of this study from our work, due to their exclusion of REIT-financing of low-income housing through social purpose REITs. Of course, we do not deny that housing is infrastructure too; but with the worrying spate of housing deficit that has deprived the dominant low-income demography in emerging economies (Ewurum et al, 2020), there is need for a perceptional change on the role of REITs in dilating lowincome housing finance. Cote et al (2013) aptly captures the narrative with the assertion, "desperate times are calling for radical thinking"; and one of such radical conceptions, from a low-income housing financing perspective, is social purpose REITs (Ades, 2016; Robaton, 2020; Cai, 2017; Huang, 2010; Huang, 2019). Still, it would not be appropriate to sidetrack some pertinent questions. First, why would a REIT invest in low-income housing?

In responding to this query, it is purposive that we take evidence from an emerging economy due to a quote we find interesting. Huang (2010) opines as follows:

"Section 8 Program makes holding affordable rental housing asset attractive for REITs".

Huang (2010) was assertively referring to Section 8 of the Housing and Community Development Act of China which allows tenants to hold a maximum of $30 \%$ rent-to-income proportion, while the income deficit of the Landlord will be offset by the government. The implication is that through this rent subsidy, low-income households pay affordable rent, while social purpose REITs receive rent at the market rate, and the government 
avoids related vices to low-income housing deficit. A win-win for all. This presents an important lesson for emerging economies, though it is pertinent to stress that its efficiency rests on the extent to which rent is regulated in the concerned economy. Besides, the aforementioned lessons Section 8 provides, is a useful answer to our initial query and a nexus to the second query. So, to what extent is this a solution to the ubiquitous housing crisis in emerging economies?

Approaching the query from a Turkish standpoint, Coskun (2011) conducted an experimental research to analyze the effect of alternative financing, through subsidies, on significant reduction of the housing crisis in Turkey. Upon qualitative analysis of data on private rental housing, social rental housing, urban renewal, microfinance, and REITs as low-income housing finance alternatives, the study found that the activities of REITs in Turkey were not directed to the provision of affordable housing due to a focus on middle and high-income groups. This informed the conclusion that REITs would improve housing affordability through optimal redesigning to prioritize the low-income group, and fiscal support by the Turkish government.

Taking the special features of the Chinese real estate and capital market into account, Liu et al (2013) investigated the applicability of REITs in financing low-rent housing through an agent-based simulation model. The model assumed that only primary market information is worthy of consideration for IPOs by low-rent housing REITs, while also considering profitability information in the secondary market. As a result, the study employed regression in testing the hypothesis that "if the expected earning of low-rent housing REITs in the primary market (risk premium deducted) is higher than the expected interest income of bank deposits, the investors will choose to purchase REITs". The hypothesis was confirmed as true, and it was further found that REIT-financing of low-rent housing in China was influenced by level of government subsidy, market fixed interest rate, and dividend proportion of low-rent housing REITs.

Still in China, Huang (2019) conducted a qualitative explanatory collective case study analyzing the use of REITs as an alternative source of financing affordable housing in one of Chinese major cities, Nanjing. Data was collected through semi-structured in-depth interviews and document reviews. The interviews featured one-to-one and face-to-face techniques, and obtained data was subjected to content analysis on NVivo. It was found that free of stringent investment policies in China, social purpose REITs presented a workable solution to dilating lowincome housing finance in the region.

\subsection{Social Purpose REIT Case Studies}

To counter the inadequacy of literature on low-income housing financing through social purpose REITs, we present sample case studies of its operationalization. Without prejudice, we examine empirical reports on two social purpose REITs - Community Development Trust and Housing Partnership Equity Trust.

\section{Community Development Trust (CDT): A Hybrid REIT}

CDT, founded in 1998, has a business commitment to the ameliorated delivery of low-income housing through the provision of long-term equity and debt capital - making it a hybrid REIT. It drew its venture capital from Local Initiatives Support Corporation - a community development intermediary. The CDT management board comprises community development and finance experts, thus providing the needed professional management service to lowincome housing projects. The CDT website reports that the company has invested over $\$ 1.9$ billion in over 48,000 "affordable units" benefiting more than 125,000 residents in 44 States across the US.

Corporate activities of the Trust comprise the purchase, holding and securitization of mortgages from a debt perspective; and the purchase, preservation and funding of affordable rental properties, from an equity perspective. It partnered with community lenders (offering $90 \%$ senior interest per loan) in its debt programme by creating a secondary market for smaller loans under $\$ 3$ million, and provided tax-deferred investment for shareholders for sustained affordability in its equity programme.

II. Housing Partnership Equity Trust (HPET): An Equity REIT

Obviously, as the name implies, HPET is an equity REIT. Established in 2013 by the Housing Partnership Network - a business collaboration between affordable housing investors and 14 nonprofits in the US, it utilizes the impact investment strategy in addressing the rental affordability crisis through the funding of low-income housing. It sourced its venture capital from Prudential Insurance Company.

Part of its corporate strategy is the purchase of multi-dwelling units within $50-80 \%$ area median income at the risk of being redeveloped into higher-priced units, with a view to preserving their affordability. The company then fixes rent at $57.4 \%$ of area median income. With this approach, Ades (2016) reports that the company has raised over $\$ 85$ million in equity which was invested in the purchase of 12 properties, in 5 states, with more than 2,600 apartments.

\section{Lessons for Emerging Market REITs}

Sgro (2017) studied the benchmarking potentials of American social purpose REITs in financing affordable rental housing in Ontario, Canada. The paper was anchored on the research question which queried the extent of implementing American social purpose REIT models in a Canadian context, citing the Housing Partnership Equity 
Trust and the Community Development Trust models. Upon the qualitative analysis of secondary data obtained from the US and Canadian real estate and banking industries, the study adopted the HPET model as best suited to ameliorating low-income housing delivery through social purpose REIT in Canada.

From our review of related literature, there is little evidence from studies that have examined social purpose REITs that suggests that firstly, Sgro's (2017) lead has been followed by other emerging market REITs; nor secondly, that social purpose REITs (in whatever nomenclature) has been widely adopted in emerging economies, outside China. Conceivably, the closest, emerging market literature has come in REIT-financing of low-income housing, is the paper by Olanrele et al (2019) on the place of social housing in REIT subscribers home ownership system for home price reductions. The study adopted a qualitative method comprising content analysis of existing research on housing and a focus group discussion with 13 experts in the built environment sector who are also academics. The result indicates that the Public Private Partnership (PPP) strategy adoption in housing delivery produces housing units beyond the reach of low-income earners. Therefore, they advocated for the involvement of a REIT in social housing delivery through occupant-subscription of the REIT company.

However, our focus transcends the adoption of occupant-subscriptions towards an extended financial pooling for low-income housing delivery. Lack of emerging market-based literature on this aspect illustrates the difficulty in locating and integrating emerging market perspectives of social purpose REITs. In several instances, an extensive body of emerging market literature on social purpose REITs does not exist, and has instead been supplemented with Chinese examples. Yet, social purpose REIT is a quicker platform for generating capital for low-income housing delivery (Robaton, 2020; Sgro, 2017; Ades, 2016), desperately needed by majority of emerging economies (Afolayan, 2017). To enhance its adoption by emerging market REITs, what lessons are pertinent?

i. Implementation of Tax Credits to Support Social Purpose REITs

Real estate investors require subsidies equivalent to or greater than the revenue generated from reduced rents for low-income housing units, to effectively account for lost revenue (Bratt, 2016; Sgro, 2017). Offering a quite interesting analogy in this respect, Ballard (2003) extrapolates that such investment incentives and subsidies "aims to house poor people. But not ones so poor that they cannot pay rents sufficient to preserve a profit for the developers". Successful adoption of social purpose REITs by emerging markets relies on credit enhancements such as tax neutrality and other fiscal incentives by government (Liu et al, 2013).

This is evident in the US and Canada Low-Income Housing Tax Credit (LIHTC), which was created in 1986 to foster private-sector involvement in low-income housing delivery. Lending credence, Clarke (2012) avers that the LIHTC offers tax credits to incentivize investment in the rehabilitation and production of affordable rental housing, resulting in the development of over 600,000 low-income housing units in the first 10 years (Sgro, 2017). LIHTC critiques claim that it focuses development in racially concentrated neighbourhoods (Bratt \& Lew, 2016). However, the criticism may be rather erroneous for situations with strict adherence to the low-income demography, and housing providers would hardly be held liable if a certain race dominates such neighbourhood.

ii. $\quad$ Policy Anchoring REITs to Indemnificatory Housing

Indemnificatory housing, also referred to as social housing in some quarters, is a government-backed nonmarket housing programme. Nonmarket housing refers to subsidized housing delivery system anchored on a state and nonprofit collaboration strategy (Sousa \& Quarter, 2004). This approach is exemplified by Section 8 of the China Housing and Community Development Act. A pertinent lesson for emerging markets here is the implementation of $30 \%$ rent-to-income proportion maximum, while the income deficit of the social purpose REIT will be equipoised by the government.

For poorer countries, the challenge of implementing this rests on the fact that rent is continuous and offsetting the deficit for investors may be too much of a burden. To curb this, we advocate for fostering REIT capitalization of low-income housing delivery through the increase of dividend proportions, so as to generate more funds through a larger pooling of investor capital. If implemented, in addition to the liquidity and professional management attributes of REITs, shareholding for social purpose REITs would be largely encouraged.

iii. Revamping of the Mortgage System

With the unsustainable housing deficit in many emerging economies (Ewurum et al, 2019), there is need for a substantial review of the mortgage policy. Presenting a possibility for strategic improvement of the mortgage industry, Huang (2010) posits that "REITs can amplify return on affordable housing through mortgage tranche". Mortgage tranche is a breakdown of mortgage obligations into smaller units for the purpose of selling them to investors. Citing the CDT REIT, Huang (2010) avers that CDT amplified returns from low-income housing by purchasing mortgages, and selling them in tranches, offering a long-term equity and debt capital with high riskadjusted returns to investors. Where the government in an emerging market revamps its mortgage system to encourage such practices, mortgage or hybrid social purpose REITs like CDT would be able to achieve a return level attractive enough to its shareholders.

iv. Development Cost Waivers for Low-Income Housing Developers

With respect to this point, it would be pertinent to issue a reminder to governments in emerging economies. Among 
the corporate objectives of HPET, as contained in "The Notes to Consolidated Financial Statements" of their Financial Statements, is number 3 on "lessening the budget of government". Therefore, social purpose REITs should primarily be viewed as a development partner to the government, instead of a business enterprise. In lieu of this, loss of revenue accruing from development permit payments by low-income housing developers would be hugely compensated by the additional units of low-income housing developed.

Cote et al (2013) alludes to this argument with the assertion that "perhaps the most promising government incentive are mechanisms to reduce development land costs". Lending credence, the City of Toronto Private Sector Housing Roundtable adopted an inclusionary housing model that waived development costs and risks through land grants. In their 2012 report, this move was adjudged successful due to the number of investors it attracted. Research by Gladki and Pomeroy in Cote et al (2013) confirmed that in Ontario, inclusionary models that include 15 percent low-income housing units in new developments can be economical if developers are provided increased building density and exemptions from municipal fees and charges to offset the costs.

As a recent IMFG Paper suggested, Section 37 agreements that trade additional density for benefits from developers, as permitted under Section 37 of the Planning Act, can also be used for affordable housing (Cote et al, 2013). Therefore, if governments in emerging economies can adopt such inclusionary housing models as incentivized municipal policies that give social purpose REITs latitude of development cost relief and exemption, its attractiveness to real estate developers may attract shareholders to the business Trust.

\section{Conclusion}

To dilate the financing of low-income housing delivery, governments in emerging markets should adopt policies that encourage the establishment of social purpose REITs. Such policies should lend towards the implementation of tax credits to social purpose REITs and an exemption of low-income housing developers from development costs. Public-Private Partnerships for housing delivery should be reviewed to incorporate strategies that ameliorate indemnificatory housing, while the mortgage system should be revamped to accommodate mortgage tranche and long-term debt capitalization.

\section{References}

Ades, D. (2016). Preserving existing affordability through a social purpose REIT. Journal of Case Study Research, $1(1)$.

Afolayan, A.S. (2017). Exploring real estate investment trust (REIT) as a housing finance option in Nigeria. Ethiopian Journal of Environmental Studies \& Management, 10(1), 1 - 10 , doi: http://dx.doi.org/10.4314/ejesm.v10i1.1

Aliu, I., Towry-Coker, L. \& Odumosu, T. (2018). Housing policy debacle in Sub-Saharan Africa: An appraisal of three housing programs in Lagos Nigeria, African. Geographical Review, 37(3), 241256, DOI: $10.1080 / 19376812.2017 .1284005$

Boudry, W., deRoos, J. \& Ukhoy, A. (2016). Diversification benefits of REIT preferred and common stock: New evidence from a utility-based framework. Real Estate Economics, 48(1), 240-293, https://doi.org/10.1111/1540-6229.12166

Brounen, D. \& de Koning, S. (2012). 50 years of real estate investment trusts: An international examination of the rise and performance of REITS, Journal of Real Estate Literature, 20(2), 197-223

Cai, Y. (2017). The use of REITs as an alternative source to finance senior housing development in China. Master of Science, Real Estate Development, Center for Real Estate.

Chang, X. \& Estelle, Y. (2016). Why affordable housing developers should go public: REITs as an alternative source of capital for housing development. Thesis, Real Estate Development, Massachusetts Institute of Technology.

Clos, J. (2017). Housing policies: Affordable homes. Nairobi: UN Habitat

Community Development Trust (2020). Building on success. Retrieved from https://cdt.biz/about-us/history/ in May, 2020.

Coskun, Y. (2011). Does re-design of the policies on housing finance and supply help to solve housing question of Turkey? Paper presented at the 18th Annual ERES Conference, Eindhoven, Netherlands, June 15-18, http://dx.doi.org/10.2139/ssrn.1868758

Cote, A. \& Tam, H. (2013). Affordable housing in Ontario: Mobilizing private capital in an era of public constraint. IMFG Perspectives, 3

Davis, S. (1997). The architecture of affordable housing. California: University of California Press

Deng, X., Ong, S.E. \& Qian, M. (2018). Real estate risk, corporate investment and financing choice. Journal of Real Estate Finance and Economics, 57, 87-113, https://doi.org/10.1007/s11146-017-9599-y

Ebi, U. \& Kalu, I.U. (2016). Views on real estate investment financing in Nigeria. Journal of Economics and International Business Management, 4(1), 30-40

Ewurum, N.I., Aso, N.E. \& Ewurum, I.C. (2020). Housing deficit attenuation through market-oriented polycentric 
management: Evidence from Nigeria. Developing Country Studies, 10(3).

Ewurum, N.I., Egolum, C.C. \& Ogbuefi, J.U. (2019). Stakeholder strategy for sustainable public housing delivery in South East, Nigeria. Global Journal of Advanced Research, 6, (3), 78 - 94.

Gillespie, T. (2018). Collective self-help, financial inclusion, and the commons: Searching for solutions to Accra's housing crisis. Housing Policy Debate, 28(1), 64-78, DOI: 10.1080/10511482.2017.1324892

Grinis, M. \& Kasper, M. (2019). Global REIT market. UK: EYGL

Hardin III, W., Hill, M. and Hopper, J. (2009). Ownership structure, property performance, multifamily properties, and REITs. Journal of Real Estate Research, 31(3), 285-306.

Huang, J. (2019). A study of using REITs as an alternative way of financing affordable housing in Chinese major cities, based on the context of Nanjing. PhD thesis.

Huang, Y. (2010). An investigation into the use of REITs to finance affordable housing in Mainland China. Master in City Planning, Department of Urban Studies and Planning.

Kallergis, A., Angel, S., Blei, A., Sanchez, N. \& Lamson-Hall, P. (2018). Housing affordability in a global perspective. Working Paper WP18AK1, Lincoln Institute of Land Policy

Kieti, R.M. \& K'Akumu, O.A. (2018). Critical factors affecting affordability of mortgage housing in Kenya. Journal of Housing and the Built Environment, 33, 111-131. https://doi.org/10.1007/s10901-0179547-4

Kyro, R., Heinonen, J. \& Junnila, S. (2012). Housing managers key to reducing the greenhouse gas emissions of multi-family housing companies? A mixed method approach. Building and Environment, 56, 203-210.

Li, Y., Cao, H. \& Zhao, T. (2018). Factors affecting successful equity crowdfunding. Journal of Mathematical Finance, 8(2), 10.4236/jmf.2018.82028

Lin, Y.C., Lee, C.L. and Newell, G. (2019). The significance of residential REITs in Japan as an institutionalised property sector. Journal of Property Investment \& Finance, 37(4), 363-379. https://doi.org/10.1108/JPIF-032019-0036

Liu, X., Wu, D., Li, X. \& Dong, J. (2013). Financing of low-rent housing REITs in China. Journal of Systems Science and Information, 1(1).

Marzuki, M.J. and Newell, G. (2018). The emergence of Spanish REITs. Journal of Property Investment \& Finance, 36(5), 495-508, https://doi.org/10.1108/JPIF-05-2018-0032

Marzuki, M.J. and Newell, G. (2019). The evolution of Belgium REITs. Journal of Property Investment \& Finance, 37(4), 345-362. https://doi.org/10.1108/JPIF-03-2019-0029

Montgomery, N., Squires, G. \& Syed, I. (2018). Disruptive potential of real estate crowdfunding in the real estate project finance industry: A literature review. Property Management, 36(5), $597-$ 619, https://doi.org/10.1108/PM-04-2018-0032

Moosa, I. (2020). Stock market contagion in the early stages of the global financial crisis: The experience of the GCC Countries. International Journal of Banking and Finance, 1(7), 19-34

Muyingo, H. (2016). Challenges in property management within the Swedish cooperative housing sector. Stockholm. Retrieved from http://urn.kb.se/resolve?urn=urn:nbn:se:kth:diva-181911 in January, 2020.

Newell, G. and Marzuki, M.J. (2018). The emergence and performance of German REITs. Journal of Property Investment \& Finance, 36(1), 91-103. https://doi.org/10.1108/JPIF-01-2017-0001

Olanrele, O.O., Adegunle, T.A., Jolaoso, B.A. \& Bin Said, R. (2019). Social housing and REIT funding for affordable housing in African developing nations. Paper presented at The Bartlett School of Construction and Project Management International Conference Bartlett Real Estate Institute, the Case of Affordable Housing: A global perspective on financing and institutional ownership, September, 12

Owusu-Manu, D., Edwards, D., Badua, E., Donkor-Hyiaman, A. \& Love, P. (2015). Real estate infrastructure financing in Ghana: Sources and constraints. Habitat International, 50, Pages 35-41

Riëtte, C. and Freybote, J. (2018). The impact of introducing REITs on foreign investments and liquidity in South Africa. Journal of Real Estate Literature, 26(1), 103-128.

Robaton, A. (2020). REITs take on affordable housing problem. Real Assets Adviser, 7(3)

Sani, N. \& Rahim, A. (2015). Price to income ratio approach in housing affordability. Journal of Economics, Business and Management, 3(12), DOI: 10.7763/JOEBM.2015.V3.357 1190

Sgro, A. (2017). Creating value: Using social purpose real estate investment trusts to support affordable housing. Master of Planning in Urban Development, Ryerson University, Ontario, Canada

Sousa, J. and Quarter, J. (2004). Non-market housing models in Ontario: A stakeholder analysis. Canadian Journal of Urban Research, 13(2), 220-240

Strauss, W. (2018). Real estate investment trusts: The current state of tax research. Dissertation, University of Pretoria.

Suhaida, M., Tawil, N., Hamzah, N., Che-Ani, A., Basri, H. \& Yuzainee, M. (2011). Housing affordability: A conceptual overview for house price index. Paper presented at the 2nd International Building Control Conference 2011, Procedia Engineering 20, 346 - 353 
Vismara, S. (2018). Signaling to overcome inefficiencies in crowdfunding markets. In: Cumming D., Hornuf L. (eds). The Economics of Crowdfunding. Cham: Palgrave Macmillan

World Bank Group (2015). Stocktaking of the housing sector in Sub-Saharan Africa: Summary report. Washington: The World Bank

Zhang Y., Yuan, W. and Lin, J. (2012). The REITs applied research of indemnificatory apartments financing. In: Zhang L., Zhang C. (eds). Engineering Education and Management. Lecture Notes in Electrical Engineering, 1(112). Springer, Berlin, Heidelberg 